\title{
Innovative teaching foreign languages
}

\section{Nishanov Sh.T ${ }^{1}$ Suyunova G.H ${ }^{2}$}

Jizzakh regional center of retraining and in-service training

\begin{tabular}{l}
\hline ARTICLE INFO \\
\hline Article history: \\
Received September 2020 \\
Received in revised form 15 \\
September 2020 \\
Accepted 25 September \\
2020 \\
Available online \\
1 October 2020 \\
\end{tabular}

\section{Keywords:}

Innovative ideas

Interactive method

Storyboard teaching

Brainstorming

Creativity

Effective tools

Creative teaching

\begin{abstract}
This article reveals some innovative ideas and activities that are sure to help and motivate teachers to reinvent their teaching methods and make their classes more interesting and fun for students.
\end{abstract}

2181-1415/C) 2020 in Science LLC.

This is an open access article under the Attribution 4.0 International (CC BY

4.0) license (https://creativecommons.org/licenses/by/4.0/deed.ru)

\section{Чет тилларини инновацион ўқитиш}

\section{Калит сузллар:}

Инновацион ғоялар

Интерактив усул

Хикоялар ўқитиш

Браинсторминг

Ижодиёт

Самарали воситалари

Ижодий ўқитиш

\begin{abstract}
АННОТАЦИЯ
Ушбу мақола ўқитувчиларга ўқитишнинг мутлақо янги усулларини ишлаб чиқишга ва дарсларни янада қизиқарли ва мазмунлии ўтказишга ёрдам берадиган ва рағбатлантирадиган баъзи бир инновацион ғоялар ва тадбирларни очиб беради.
\end{abstract}

\footnotetext{
${ }^{1}$ Head of the Chair of Language Teaching Methods in Jizzakh regional center for retraining and advanced training of public education staff email: jizzax2020@yandex.ru

${ }^{2}$ Senior Teacher of the Chair of Language Teaching Methods in Jizzakh regional center for retraining and advanced training of public education staff"
} 


\section{Инновационное обучение иностранным языкам}

\author{
Ключевые слова: \\ Передовые идеи \\ Интерактивный метод \\ Обучение раскадровке \\ Мозговая атака \\ Креативность \\ Эффективные средства \\ Творческой \\ педагогической \\ Деятельности
}

\section{АННОТАЦИЯ}

В этой статье раскрываются некоторые инновационные идеи и мероприятия, которые помогут и будут мотивировать преподавателей изобретать совершенно новые методы обучения студентов и делать занятия более интересными и увлекательными.

Nowadays, everyone knows that we live in the age where technology is highly developed and is changing day by day. And today for us, educators, the biggest challenge is capturing each student's attention and convey ideas and activities effectively enough in order to create a lasting impression. As a teacher to deal with this challenge effectively we should implement some innovative ways and ideas that make the classroom experience much more enjoyable and lovable for our students. We must encourage our students to be active members of our class, thinking on their own, using their own brain and resulting in long term memory. By doing this we improve not only the students' knowledge, but we will increase their interest, strength, knowledge, team spirit and freedom as well. In this article I will talk about some innovative and interactive ideas as well as activities that are sure to help teachers reinvent their teaching methods. They maintain to make their classes more interesting and fun for learners. These innovative ideas encourage educators to use different types of warm-up activities like brainstorming, storyboard teaching, audio and video tools, role play and various structures, work together as a team, as well as creative teaching. By using them in classes we bring aspects of creativity into our classes, encourage various ideas, give our students the freedom to explore and they are sure to excite young minds and capture their interest [2]. As Hernan Avila stated, there is a need to be aware of innovative and powerful strategies for the improvement of learning a foreign language in an academic setting. In order to be fully prepared and confident in the classroom, teachers should look for what is suitable in their particular educational context. Educators should consider potential and creative teaching options to overcome students' learning challenges such as their lack of interest and attention in the subject [1]. Teachers take on a role of authority in the eyes of the students, which greatly influences pupils' learning process (Burns \& Richards, 2009). It is important for teachers to give students a sense of what to expect in the course while making the class fun, entertaining, and beneficial for the learners [3]. Throughout this article, I intend to provide helpful strategies, which teachers may rely on to use in the classroom where they will be teaching. In order to solve problems and have innovative activities to reach out to students, instructor has to be creative. In this article, I will talk about the use of innovative ideas for teaching, encourage them to give more dedication towards the lesson material and lesson planning as well as highlight the sufficient effects of them in the classes. We will get acquainted and also reinvent some interactive teaching tools and interactive/ innovative teaching ideas.

Let's state out some of the ideas which are very useful and necessary in the 21st century. Creative teaching is one of the leading strategies in teaching as it maintains to 
identify students' creative abilities and encourage them to make creative ideas and contributions. So, include and use different playful games or forms of visual exercises that will excite young minds and capture their interest. We have to think of ways to develop learners' creative ideas, encourage different ideas, and give them freedom to explore [2]. Brainstorming, a useful tool to develop creative solutions to a problem, is a lateral thinking process by which students are asked to develop ideas or thoughts that may seem crazy or shocking at first. Brainstorming sessions are a great way to get the creative juices flowing. When you have multiple brains focusing on one single idea, you are sure to get numerous ideas and will also involve everyone into the classroom. Brainstorming can help define an issue, diagnose a problem, or possible solutions and resistance to proposed solutions. You can go for simple brainstorming or joined brainstorming. Educators should always implement and incorporate audio-visual materials to supplement textbooks during the lesson and session in order to enhance learning resources by showing real life scenarios, explaining concepts, observing social groups, and acting as triggers for discussion. These can be models, filmstrips, movies, pictures or other mind mapping and brain mapping tools. Such tools help their imagination thrive and develop and these methods will not only develop their ability to listen but will also help them understand the concepts better. Realworld learning and using authentic materials in the classroom is another very useful strategy, as relating and demonstrating through real-life situations will make materials easy to understand and easy to learn. It will spark their interest and get children excited and involved. They will make teaching moments fresh, and enrich classroom learning. Working together as a team is another useful tool which increases collaboration and allows brainstorming. As a result, more ideas are developed and productivity improves. Two or more people are always better than one for solving problems, finishing off difficult tasks and increasing creativity. The benefits of teamwork include increased efficiency, the ability to focus different minds on the same problem and mutual support. It maintains collaborations and introduces innovative teaching methods. As Rudyard Kipling said, "If history were taught in the form of stories, it would never be forgotten." Storyboarding is a great way to teach any subject which requires step-by-step memorization or visualization of highly conceptual ideas. Being EFL teachers we can also encourage use of storyboards of communication and let the students tell a story in pictures. Storyboarding can be compared to spreading students' thoughts out on a wall as they work on a project or solve a problem. Storyboards can help with planning ideas, communications and organization. This method allows students to see the interconnections, how one idea relates to another, and how pieces come together. Once the ideas flow, students become immersed in the problem and tag-team off other ideas [4]. We, teachers must welcome new ideas, as an open-minded attitude can help us in innovating new teaching methods. Though we might claim to be open-minded, it's human nature to resist change. So, let's evaluate ourselves and ensure us try out new ideas in the classroom. Referring to books on creativity is another brilliant idea in teaching. In order to be a good teacher, to be a creative teacher, we need to do some research on creative ideas and techniques, for this there are a lot of books on creativity. The real task and demand of today's education is not to entertain students but engage them and our charge is to provide meaningful and powerful engagement which leads to success. We educators shouldn't be afraid of experimenting and reflecting on their teaching. We have to try welcome out new ideas, adapt new ideas, 
stop on time and evaluate the experience when done, they must always learn from successes and your mistakes and also make this a regular part of their teaching. We, teachers must make creativity part of our daily routine and look at everything we do with critical way, practice our creativity, be involved in brain- training activities.

\section{References}

1. Avila H.A., 2015. Creativity in the English class: Activities to promote EFL learning. HOW, 22 (2), 91-103

2. English Teaching Forum. Volume № 1, 2011.

3. Knapen Ruben, 2018. 20 Interactive teaching activities in interactive classroom.

4. The Internet TESL Journal, Vol. V. № 5. May, 1999. http://iteslj.org/ 